\title{
Characteristic of selected rheological parameters of stallion ejaculate*
}

\begin{abstract}
Dynamic viscosity of native (30 minutes after ejaculation) and 24 hours stored $\left(a t 4^{\circ} \mathrm{C}\right.$ ) stallion ejaculate was measured. The ejaculate from 10 breeding stallions was examined in three different experimental series. The average value of dynamic viscosity at shear rate $1.02 \mathrm{~s}^{-1}$ was found to be $416.8 \pm 10.1 \mathrm{mPa}$.s. The correlation between ejaculate volume, sperm concentration and viscosity was tested. The experiments resulted in finding a dependence between increasing viscosity and decreasing sperm concentration $\left(\mathrm{r}_{\mathrm{p}}=-0.67 ; \mathrm{P}<0.05\right)$. Performed experiments with changing shear rate demonstrated non-Newtonian characteristics of stallion ejaculate with a clear shear-thinning behaviour. Stallion ejaculate appeared to be slightly time-dependent liquid.
\end{abstract}

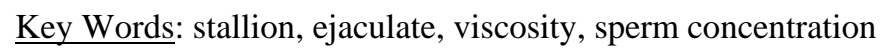

\section{Zusammenfassung}

\section{Titel der Arbeit: Verhalten ausgewählter rheologischer Merkmale von Hengstejakulaten}

Sowohl an nativen (30 Minuten nach der Absamung) als auch an gelagertem (24 h bei $4^{0} \mathrm{C}$ ) Hengstsperma wurden, unter drei unterschiedlichen experimentellen Bedingungen, die dynamische Viskosität der Ejakulate von 10 Hengsten untersucht. Bei einer Deformationsgeschwindigkeit von $1,02 \mathrm{~s}^{-1}$ betrug der Durchschnittswert der dynamischen Viskosität 416,8 $\pm 10,1 \mathrm{mPa}$.s. Die Beziehungen zwischen Ejakulatvolumen, Ejakulatviskosität und Ejakulatkonzentration ergaben eine Abhängigkeit zwischen steigender Viskosität und abnehmender Ejakulatkonzentration mit einem Korrelationskoeffizienten von $r_{p}=-0,67 ; \mathrm{P}<0,05$. Die Messungen zeigten auch, dass Hengstejakulat eine non-Newtonsche Flüssigkeit mit einem shear-Verdünnungs-Verhalten ist. Es ist zu schlussfolgern, dass Hengstsperma eine geringfügig zeitabhängige Flüssigkeit ist.

Schlüsselwörter: Hengst, Ejakulat, Viskosität, Ejakulatkonzentration

\section{Introduction}

The factors influencing physical properties of ejaculate are extremely numerous and of different origin. Among the important ones are: donor's age, the time of sperm placement in speramtic cord, the time period between and after ejaculation, sperm ageing - morphological, physiological, and biochemical, energy reserve, membrane transport, bounding proteins, hydrodynamics, $\mathrm{pH}$, temperature, and others.

Observing of physical properties of stallion ejaculate, their following evaluation and possible standardizing, is complicated by huge variation in ejaculates from different stallions, and even among ejaculates collected from the same stallion (ROUSSET et al., 1987; KATILA et al., 1997). The correct handling with fresh stallion ejaculate and assessing the quality of raw ejaculate is broadly described e.g. in MALMEGREM (1997). Physical properties of semen (as a testing material) are time-dependent (SHI et al., 2004) and their comparison and evaluating is thus complicated. Biophysical and biomechanical characteristics of semen collected by artificial vagina are described in

\footnotetext{
* This research was supported by project of MSMT - MSM 6215648905.
} 
MOSAFERI et al. (2004). Description of changes in sperm morphology after ejaculation can be found in GATTI et al. (2004).

Mammalian ejaculate rheological characteristics are highly variable and depend on many conditions. Interfacial rheological properties of adsorbed protein layers are broadly studied in BOS et al. (2001). Several papers analysed viscosity values and examined the influence of different factors such as time after ejaculation (SHI et al., 2004), effects of enzymes (BRAVO et al., 2000), etc.

Studies on the biophysical and biochemical characteristics of semen are essential for semen processing and preservation and artificial insemination. Until recently, semen analysis in most mammalian species was based on standard microscopical techniques determining the main sperm parameters, i.e. the sperm concentration, motility and morphology. The problems, which arise when using these microscopical methods, are subjectivity and variability, possibly resulting in erroneous or conflicting conclusions (RIJSSELAERE et al., 2003). Especially, sperm motility assessment is difficult and is influenced by temperature and the evaluator's skills, leading to high variability among laboratories and observers. All these factors implicate a need for objective and standardized methods, both for practical and research purposes. But there is an absence of noted works examining the correlation between stallion ejaculate dynamic viscosity and sperm concentration or ejaculate volume as a possible tool for predicting quality parameters. The aim of this work is to describe selected rheological properties of stallion ejaculate, determine the changes induced by one-day storing, and find possible relation between biological parameters (such as sperm concentration and ejaculate volume) and rheological parameters.

\section{Material and Methods}

The values of ejaculate dynamic viscosity were observed for 10 stallions (hereinafter denoted as No.1 - No.10) housed in horse-breeding farm. The ejaculate collecting was performed on a regular base - two times a week. Monitored samples of ejaculate were collected in spring months, in 3 stages (denoted as on site I, on site II, and on site III). There were 2-week intervals between individual stages (collecting and measuring dates). Measuring was performed on site (in the laboratory conditions) in compliance with fresh ejaculate handling rules (KATILA, 1997). Viscosity measuring was performed immediately after ejaculation. The majority of semen samples was milky in color and consistency. Ejaculate volume and sperm concentrations were determined as a complementary biological measurings and factor possibly correlating with physical properties. The sperm concentration was determined by means of Bürker's cells method. The second day measuring (24 hours after first one) was performed on ejaculate stored at $4^{\circ} \mathrm{C}$ in university physical laboratory. The temperature conditions of each experiment were carefully monitored.

Rheological data were obtained from measurements performed on laboratory Anton Paar DV-3 P Digital Viscometer, which is designed to measure dynamic viscosity, shear stress $(\tau)$, and shear rate $(\gamma)$. The DV-3 P is a rotational viscometer, based on measuring the torque of a spindle rotating in the sample at a given speed. Shear stress is expressed in $\left[\mathrm{g} . \mathrm{cm}^{-1} . \mathrm{s}^{-2}\right.$ ], shear rate in $\left[\mathrm{s}^{-1}\right]$, viscosity in [mPa.s], and speed of spindle in revolutions per minute [rpm]. The experiments were performed with use of a small sample adapter with TR9 spindle. The small sample adapter permits more accurate measurements than standard device equipped with another spindle type. Also the 
measuring range of viscometer can be extended. Due to the parallel cylinder geometry, shear stress, except other values, can be determined.

The non-Newtonian ejaculate viscosity was modeled using simple mathematical models. Curve fitting application (MATLAB) was used. Model (1) and below listed parameters were used and satisfying result of $\mathrm{R}^{2}=0.99$ was achieved.

$$
\text { model (1) } \eta=a \dot{\gamma}^{b}+c
$$

$\mathrm{a}=452.8 \mathrm{mPas} ; \mathrm{b}=-0.9212 ; \mathrm{c}=-10.73 \mathrm{mPas} ; \mathrm{R}^{2}=0.99$

The time-dependent viscosity of ejaculate was measured at constant shear rate of 1.02 $\mathrm{s}^{-1}$. Also this experiment was modeled - see Model (2). Model (2) resulted in very good agreement of calculated and experimental data $\mathrm{R}^{2}=0,93$.

$$
\text { model (2) } \eta=a_{o}+\sum_{n=1}^{n=8} a_{n} \cos (n \omega t)+b_{n} \sin (n \omega t)
$$

$\begin{array}{llll}\text { a1 (mPas) } & 13.59 & \text { b1 (mPas) } & -24.55 \\ \text { a2 (mPas) } & 13.94 & \text { b2 (mPas) } & -29.17 \\ \text { a3 (mPas) } & 3.41 & \text { b3 (mPas) } & -26.30 \\ \text { a4 (mPas) } & -4.60 & \text { b4 (mPas) } & -18,22 \\ \text { a5 (mPas) } & -10.67 & \text { b5 (mPas) } & -9.56 \\ \text { a6 (mPas) } & -10.35 & \text { b6 (mPas) } & -4.72 \\ \text { a7(mPas) } & -8.06 & \text { b7 (mPas) } & -3.60 \\ \text { a8 (mPas) } & -1.94 & \text { b8 (mPas) } & -1.98\end{array}$

Results and Discussion

The ejaculate samples from different stallions varied to certain degree in all monitored parameters - dynamic viscosity value, sperm concentration and ejaculate volume. The average volume of studied ejaculate was found to be $41.10 \pm 27.00 \mathrm{~cm}^{3}$, average sperm concentration $0.37 \pm 0.2810^{9} . \mathrm{cm}^{-3}$, average spermatosoa motility $66.50 \pm 8.40$ $\%$, and average dynamic viscosity value measured at shear rate $1.02 \mathrm{~s}^{-1}$ was found to be $416.8 \pm 10.1 \mathrm{mPa} . s$. The example of viscosity measuring data (on site I measuring) for above stated shear rate is given in Table 1 .

Table 1

Viscosity of the stallion ejaculates - measuring ON SITE I, shear rate $1.02 \mathrm{~s}^{-1}$ (Dynamische Viskosität des Hengstejakulates - Abmessung ON SITE I, die Deformationsgeschwindigkeit $1.02 \mathrm{~s}^{-1}$ )

\begin{tabular}{ccccccccccccc}
\hline Sample No. & 1 & 2 & 3 & 4 & 5 & 6 & 7 & 8 & 9 & 10 & $\bar{x}$ & $\mathrm{~s}_{\mathrm{x}}$ \\
\hline$\eta[\mathrm{mPa} . \mathrm{s}]$ & 390 & 418 & 421 & 413 & 418 & 422 & 419 & 413 & 424 & 430 & 416.8 & 10.1 \\
\hline
\end{tabular}


The correlation between ejaculate volume and viscosity (measured at $\gamma=1.02 \mathrm{~s}^{-1}$ ) was found to be weak $\left(r_{p}=0.23 ; \mathrm{P} \leq 0.05\right)$, which shows on non-significant dependence between these two quantities. The stallion ejaculate viscosity (measured 30 minutes after ejaculation) thus depends on other factors, but not its volume. By contrast to this result, the correlation between sperm concentration and viscosity was demonstrated. The correlation coefficient value (significant at $\mathrm{P} \leq 0.05$ ) of $\mathrm{r}_{\mathrm{p}}=-0.67$ shows on decreasing viscosity with increasing sperm concentration.

Another experiment series was performed with objective of verifying or contradicting the influence of sharing rate on ejaculate viscosity under given temperature $21.7 \pm 0.8$ ${ }^{\circ} \mathrm{C}$, plotting the dependence curves of dynamic viscosity on shear strain rate, and creating a simple suitable model of such dependence. Table 2 contains viscosity data measured during three different field experiments (on site I, on site II, and on site III) under different shear rates. Sample No. 3 was selected as an example. Similar tables could be presented for all other samples.

The ejaculate exhibits shear-thinning behaviour, that means the dynamic viscosity decreases with shear rate. The shear thinning behaviour was expected in ejaculate since its texture is affected by weak physical bonds and hydrophobic interactions.

Table 2

Ejaculate viscosity values measured for different rates of shearing - on site (sample No. 3 selected as an example) (Ejakulatviskositätswerte für verschiedene on site Deformationsgeschwindigkeiten (Beispiel Probe 3))

\begin{tabular}{cccc}
\hline & \multicolumn{3}{c}{$\eta$ [mPa.s] of sample No. 3 } \\
\hline shear rate $\left[\mathrm{s}^{-1}\right]$ & on site I & on site II & on site III \\
\hline 0,102 & 3695 & 2933 & 3610 \\
0,17 & 2300 & 1861 & 2080 \\
0,34 & 1245 & 1150 & 1213 \\
1,02 & 426 & 214 & 377 \\
1,7 & 227 & 115 & 205 \\
3,4 & 126 & 64 & 106 \\
17 & 29 & 28 & 26 \\
34 & 23 & 15 & 19 \\
68 & 10 & 10 & 10 \\
\hline
\end{tabular}

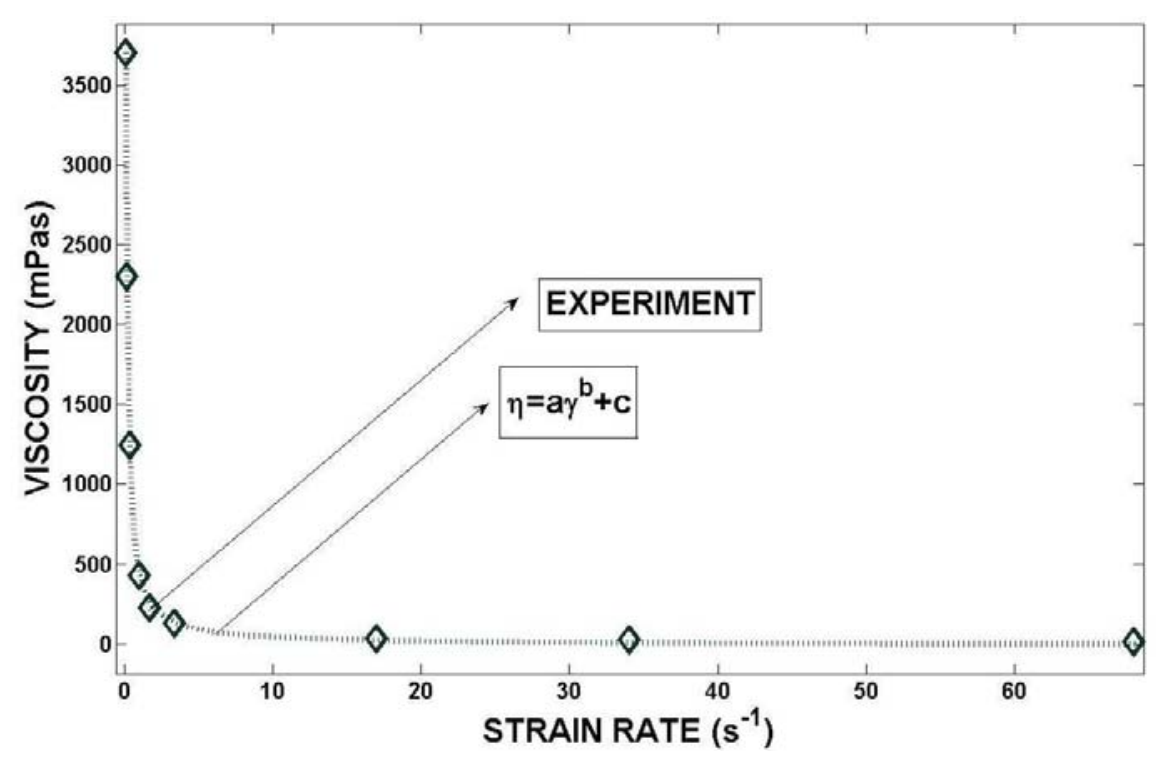

Fig. 1: Mathematical model of ejaculate flow behaviour (Mathematisches Modell des Ejakulatfließverhaltens) 
Figure 1 shows the Model (1) of flow behaviour and measured data fitting. The nonNewtonian behaviour is obvious.

The time-dependent viscosity of ejaculate was measured at constant shear rate of 1.02 $\mathrm{s}^{-1}$. Typical experiment results are shown in Figure 2. At a constant share rate, the dynamic viscosity increases relatively slowly (when avoiding starting non-relevant values) for first 20-30 minutes and then approaches a constant value corresponding to equilibrium state. Similar dependence was observed for the majority of samples. The increase can be attributed to partial internal structure creating. The rate and extent of viscosity change depend on both, applied shear rate and pre-measuring treatment.

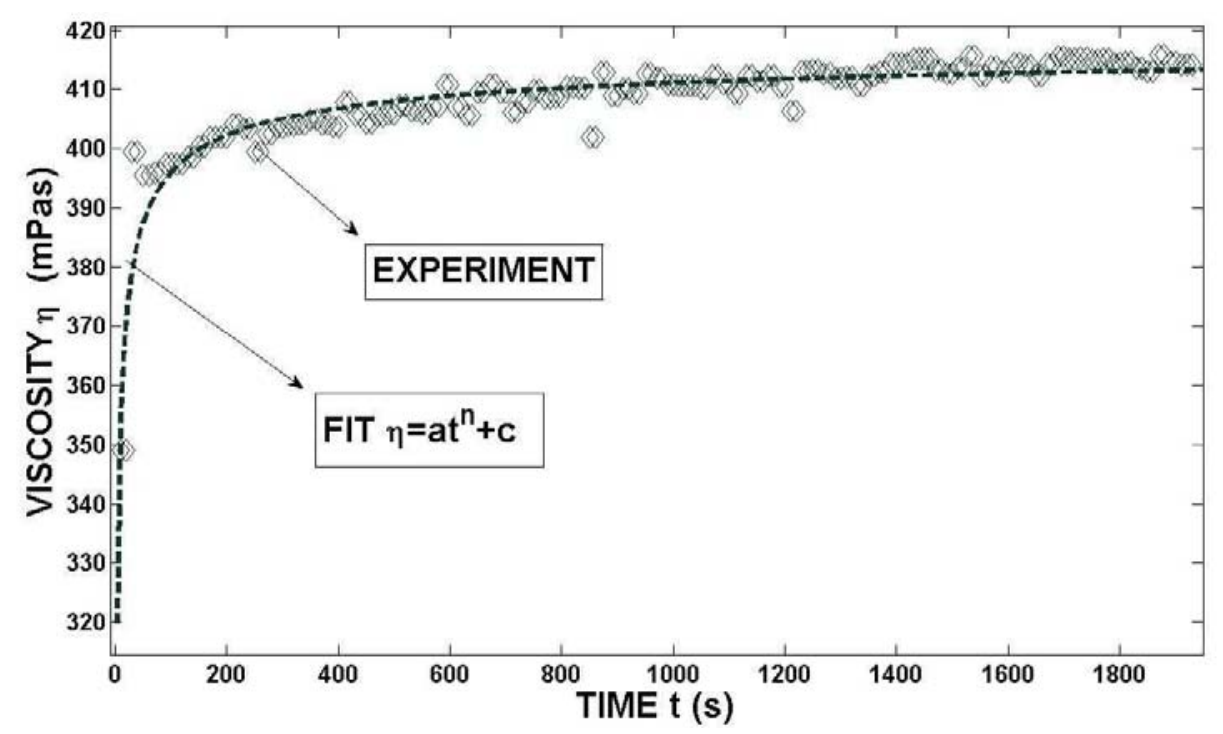

Fig. 2: Time-dependent flow properties of the ejaculate and its calculated model (Zeitabhängiges Ejakulatfließverhalten im Vergleich zum berechneten Modell)

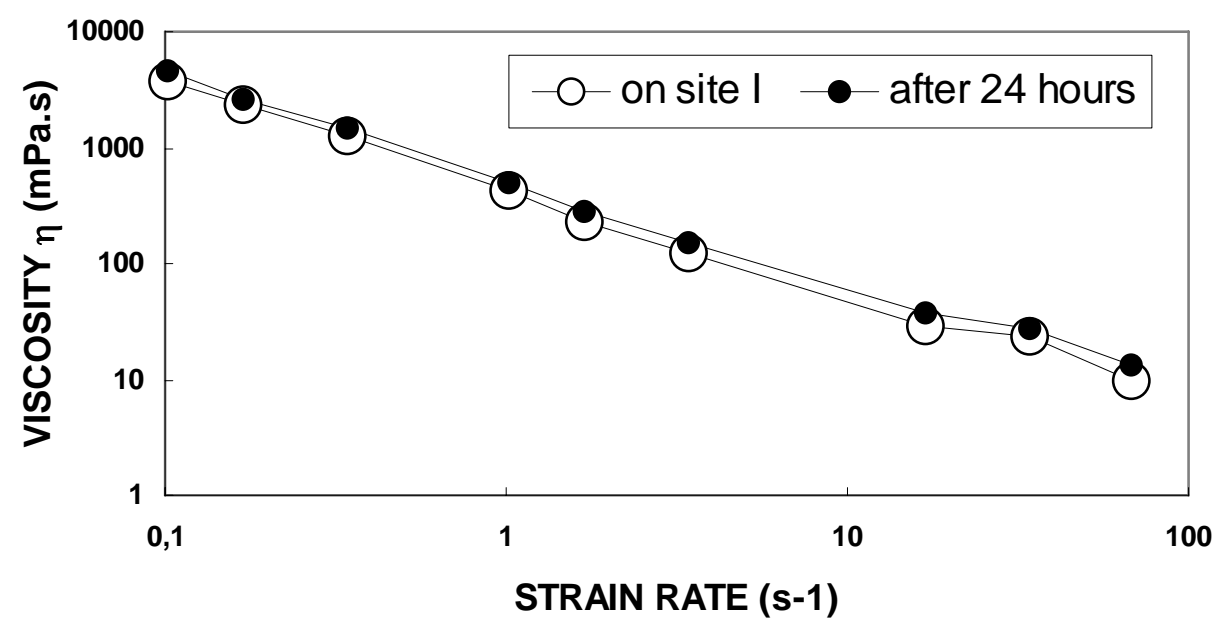

Fig. 3: Dependence of viscosity on strain rate. Comparison of ON SITE I measuring and the same experiment performed after 24 hours Fig. 3 (Abhängigkeit der Viskosität vom Fließverhalten im Vergleich des on site- mit dem 24 h Wert) 
Similar dependencies were observed for samples stored for 24 hours. The increase in viscosity values $17.7 \pm 8.4 \%$ was found when comparing native (30 minutes after ejaculation) ejaculate and 1day stored experimental material. Slight variability can be attributed to biological manner of tested material and individual characteristics and parameters of different ejaculates. Last-mentioned finding (slightly increasing viscosity) is in accordance with behaviour of other biological materials and animal products (SEVERA et al., 2005). Example of such confrontation is shown in Figure 3. Measuring of stallion ejaculate dynamic viscosity (at different share rates and different time periods after collecting) and determining other ejaculate characterictics thus resulted in several findings. The values of sperm volume and concentration are in accordance with the ones found in MÁCHAL and KŘIVÁNEK (2002). The values of spermatosoa motility are in accordance with values stated in WARNKE et al. (2001). The huge variation in ejaculates from different stallions (ROUSSET et al., 1987; KATILA, 1997) was confirmed. The volume of collected ejaculate does not affect its dynamic viscosity. There was no significant correlation found between these two quantities. On the contrary, sperm concentration seems to be in relevant correlation with viscosity $\left(r_{p}=-0.67 ; P<0.05\right)$. The viscosity decreases with sperm concentration. Obvious signs of shear-thinning were found for the ejaculate sheared at different rates. Non-Newtonian behaviour was observed for all tested samples. Tested samples indicated the characteristics of time-dependent liquids. Also finding concerning changing of viscosity values with different time after ejaculation stated in SHI et al. (2004) was confirmed.

\section{BOS, M. A.; VLIET, T.:}

\section{References}

Interfacial rheological properties of adsorbed protein layers and surfactants: a review.Advances in Colloid and Interface Science, 91 (2001), 437-471

BRAVO, P. V.; CCALLO, M.; GARNICA, J.:

The effect of enzymes on semen viscosity in Llamas and Alpacas. Small Ruminant Research, 38 (2000), 91-95

GATTI, J. L. ; CASTELLA, S. ; DACHEUX, F. ; ECROYD, H.; MÉTAYER, S.; THIMON, V.; DACHEUX, J. L.: Post-testicular sperm environment and fertility. Animal Reproduction Sciences, 82 (2004), 1217-1227

KATILA, T: Procedures for handling fresh stallion semen. Theriogenology, 48, (1997), 1217-1227

MÁCHAL, L.; KŘIVÁNEK, I.:

The specific conductivity of the stallion ejaculate and semen plasma. Acta univ. agric. et silvic. Mendel. Brun., 50 (2002), 45-52

MALMEGREN, L.:

Assessing the quality of raw semen: A review. Theriogenology, 48 (1997), 523-530

MOSAFERI, S.; NIASARI-NASLAJI, A.; ABARGHANI, A.; GHARAHDAGHI, A. A.; ERAMI, A.:

Biophysical and biochemical characteristics of bactrian camel semen collected by artificial vagina. Theriogenology, 63 (2004), 92 - 101

RIJSSELAERE, T.; VAN SOOM, A.; MAES, D.; DE KRUIF, A.:

Effect of technical settings on canine semen motility parameters measured by the Hamilton-Thorne analyzer. Theriogenology, 60 (2003), 1553 - 1568

ROUSSET, H.; CHANTELOUBE, P.; H., MAGISTRINI, M.; PALMER, E.:

Assesment of fertility and semen evaluation of stallions. J Reprod Fertil Suppl., 35 (1987), 23-31

SHI, Y.D.; PAN, L.F.; YANG, F.K.; WANG, S.Q.:

A preliminary study on the rheological properties of human ejaculate and changes during liquefaction. Asian J. Androl., 6 (2004), 299-304

SEVERA, L.; NEDOMOVÁ, Š.; KŘIVÁNEK, I.; BUCHAR, J.:

Rheological properties of ageing egg yolk. Acta univ. agric. et silvic. Mendel. brun., 53 (2005), 127-138 
WARNKE, C.; BLOTTNER, S.; KANITZ, W.:

Changes of movement and morphology in stallion spermatosoa between breeding and non-breeding season. Arch. Tierz., Dummerstorf 44 (2001) Special Issue, 184-185

Received: 2006-12-28

Accepted: 2007-10-18

Corresponding author

Ing. LIBOR SEVERA, PhD

Mendel University of Agriculture and Forestry in Brno

Zemědělská 1, 61300 BRNO / CZECH REPUBLIC

E-mail: severa@mendelu.cz 